\title{
Anna Brzezińska
}

https://orcid.org/0000-0002-5114-4034

Uniwersytet Łódzki

\section{Le noble, le serf et le révizor: Daniel Beauvois w Bibliotece „Kultury”}

Zarys treści: Przedmiotem rozważań jest obecność i recepcja prac Daniela Beauvois na łamach wydawnictw Instytutu Literackiego w Paryżu („Kultura”, „Zeszyty Historyczne”, Biblioteka „Kultury"), a także sformułowana na ich marginesie postkolonialna diagnoza napięć, jakie w polskiej tożsamości narodowej wywołała obecność na Kresach Wschodnich.

The content outline: This article presents the person of Daniel Beavois - a distinguished student of the Polish-Russian-Ukrainian relations in the post-partitioned era - and his contacts with the editors of the Paris 'Kultura'. The author's concern is also with the question of how Beavois' work on the Polish nobility in Ukraine in the years 1831-63 was received among Polish post-war exiles, and with Beavois' postcolonial diagnosis that emerged on the margins of his research and concerned the tensions to which Polish national identity was subject in Poland's old eastern borderland (the so-called Kresy).

Słowa kluczowe: Daniel Beauvois, historiografia polska XX w., Kresy Wschodnie Rzeczypospolitej, tożsamość narodowa, Biblioteka „Kultury”, postkolonializm

Keywords: Daniel Beauvois, Polish historiography in the twentieth century, Poland's old eastern borderland, national identity, the Library of 'Culture', post-colonialism

„Życzę Polakom, by historia nie była powodem do dumy, ale do myślenia”. Tymi słowy zakończył swoje wystąpienie na sesji zagranicznych badaczy dziejów Polski podczas XX Powszechnego Zjazdu Historyków Polskich w Lublinie Daniel Beauvois: francuski historyk - choć w sensie wykształcenia zawodowego nigdy nim nie był - zafascynowany nie tyle dziejami Polski, ile polskością. Anielską i imperialną zarazem. Która w jego oczach przy bliższym poznaniu straciła.

W historiografii polskiej, stosując może nieco uproszczoną metaforę, Beauvois jest francuskim odpowiednikiem Normana Daviesa. Chyba właśnie w tej kolejności. Choć ich interpretacje dziejów Polski są różne. Analogii, także w przestrzeni publicznej, nie sposób jednak nie zauważyć - ostatnio, w odstępie dwóch lat, ukazały 
się na polskim rynku wydawniczym autobiografie obydwuํ. Poza wspomnianą autobiografią autora Le noble, le serf et le révizor ${ }^{2}$, będącą tłumaczeniem wersji francuskiej, opublikowanej w 2014 r. w numerze specjalnym periodyku Instytutu Historii Nauki PAN „Organon”, można również wskazać dwie obszerne recenzje oryginału. Barwną osobowość badacza na podstawie lektury jego szkicu autobiograficznego scharakteryzował w 2017 r. na łamach „Kwartalnika Historycznego” Leszek Kuk ${ }^{3}$, a rok wcześniej w „Kwartalniku Historii Nauki i Techniki” Iwona H. Pugacewicz. Oboje mają okazję znać Beauvois osobiście.

Głębsze rozpoznanie samego procesu i kontekstu badawczego - pisała Pugacewicz - połączone z oglądem emocji i intencji kontrowersyjnie postrzeganego historyka, który odważył się kwestionować polskie mity narodowe, stało się bardziej dostępne i zrozumiałe dzięki napisanej przez niego autobiografii ${ }^{4}$.

Autobiografia historyka to zawsze cenny podarunek dla badaczy dziejów historiografii, a któż wie o tym lepiej niż uczeni francuscy ${ }^{5}$. Nie jest to jednak źródło łatwo poddające się krytyce wewnętrznej ${ }^{6}$. Na pewno ważna $z$ tej perspektywy jest ocena historyczki znającej autora wspomnień:

Bezkompromisowe[go] przełamywani[a] historycznych i narodowych stereotypów, takich jak mit polskich kresów jako utraconego raju, idyllicznych rubieży z życiodajnym kapitałem kultury polskiej czy podważenie zasad demokracji szlacheckiej, nie należy przypisywać w żadnej mierze egocentrycznemu charakterowi naukowca, brakowi pokory wobec dokonań poprzedników czy niczym nieuprawnionej potrzebie naukowej arbitralności ${ }^{7}$.

W praktyce lektury zawsze jednak pozostaje nieprzekraczalna do końca bariera między intencją nadawcy a interpretacją odbiorcy.

Wbrew życzliwej opinii autorki, która brzmi trochę jak próba uprzedzenia ewentualnej krytyki postaci Beauvois, czytając jego wspomnienia i korespondencję zgromadzoną w Archiwum Instytutu Literackiego w Maisons-Laffitte, dostrzegam,

1 D. Beauvois, Autobiografia i teksty wybrane, Warszawa 2017; N. Davies, Sam o sobie, tłum. B. Pietrzyk, Kraków 2019.

2 D. Beauvois, Le noble, le serf et le révizor. La noblesse polonaise entre le tsarisme et les masses ukrainiennes, 1831-1863, Paris 1985.

${ }^{3}$ L. Kuk, Polska $z$ bliska i $z$ oddali. Przypadek Daniela Beauvois $w$ świetle jego wspomnień, „Kwartalnik Historyczny” 124, 2017, nr 4, s. 805-820.

${ }^{4}$ I.H. Pugacewicz, rec.: D. Beauvois: Mes pierres de lune. Essai d'autobiographie professionnelle, „Organon”, nr spec. 46, Warszawa 2014, ss. 193, „Kwartalnik Historii Nauki i Techniki” 61, 2016, nr 1, s. 189.

${ }^{5}$ Zob. Essais d'ego-histoire, red. P. Nora, Paris 1987.

${ }^{6}$ Szerzej na ten temat pisałam w artykule Autoportret $z$ Klio. Ego-histoire kontra historia historyka Arona Guriewicza jako koncepcja źródła w biografii historyka, „Sensus Historiae” 17, 2014, nr 4, s. 213-223.

7 I.H. Pugacewicz, dz. cyt., s. 189. 
nierzadką przecież wśród wybitnych autorów, osobowość egotyczną, przekonaną o własnej racji (pouczał Giedroycia, jak czytać Dmowskiego) ${ }^{8}$, a niekiedy nawet - w obronie wyznawanych zasad - konfliktową (okoliczności odejścia z funkcji dyrektora Centre d'histoire des Slaves na Sorbonie ${ }^{9}$, współpraca $\mathrm{z}$ wydawcami ${ }^{10}$ i oskarżanie Jerzego Kłoczowskiego o „zdradę przyjaźni”11). Beauvois akcentuje poczucie osaczenia przez środowisko naukowe i przekonanie, że pisze/walczy w słusznej sprawie. Jeśli francuskość istnieje ${ }^{12}$, to Beauvois - jednocześnie krytykując francuską megalomanię, ignorancję polityczną, rusofilię („organiczną”), politykę naukową - byłby jej typowym przedstawicielem ${ }^{13}$. Polacy mają mu za złe ukrainofilię, rodacy - polonofilię, Ukraińcy nie są przekonani, że właściwie rozumie ich dążenia niepodległościowe ${ }^{14}$.

Wspomniany przeze mnie wyżej drugi rodzaj źródeł do niniejszego artykułu stanowi prowadzona w latach 1981-1999 korespondencja Daniela Beauvois z Jerzym Giedroyciem, zgromadzona w Archiwum Instytutu Literackiego w Maisons-Laffitte. Zbiór nieco ponad 40 listów jest w większości jednostronny (autorem jest Beauvois). Można to wyjaśnić jego odwiedzinami w Maisons-Laffitte i wzmiankowanym w listach obyczajem omawiania pilnych spraw telefonicznie. Tematyka dotyczy w przeważającej mierze kwestii wydawniczych, ale też francuskiej polityki naukowej, imigracyjnej i Polonii ${ }^{15}$.

${ }^{8}$ Archiwum Instytutu Literackiego w Maisons-Laffitte, Korespondencja redakcyjna (dalej: AIL, KR), Beauvois Daniel, List D. Beauvois do J. Giedroycia, Paryż, [7 X] 1996 r.

9 D. Beauvois, Mes pierres de lune. Essai d'autobiographie professionnelle, „Organon” 2014, nr 46, s. 109.

10 AIL, KR, Beauvois Daniel, List D. Beauvois do J. Giedroycia, Villeneuve d'Ascq, 20 II 1989 r.; D. Beauvois, Mes pierres de lune..., s. 114-115. W sporze o sposób rozliczenia honorarium, nieusatysfakcjonowany odpowiedzią J. Giedroycia, Beauvois przechodzi w korespondencji na j. francuski. Zwyczajowo pisał grzecznościowo po polsku.

${ }^{11}$ D. Beauvois, Mes pierres de lune..., s. 115.

12 Odwołując się do metafory Roberta Darntona; tenże, The Great Cat Massacre and Other Episodes in French Cultural History, New York 1984; wyd. pol.: Wielka masakra kotów i inne epizody francuskiej historii kulturowej, tłum. D. Guzowska, Warszawa 2012.

13 M. Filipowicz, Konferencja w Lille [sprawozdanie; spotkanie odbyło się 20-23 IX 1993 A.B.], „Kultura” 1993, nr 11(554), s. 58: „prof. D. Beauvois ośmielił się np. mówić bez szczególnego nabożeństwa o Wolterze i jego stosunku do Rzeczypospolitej, specyficznie powiązanym z finansowym uzależnieniem od Katarzyny II. I choć wykład był zobiektywizowany, a cokolwiek ironiczny ton autora wyjątkowo przecież pasował do przedmiotu rozważań (Voltaire!), z sali w trakcie dyskusji pojawiły się głosy sprzeciwu: ktoś ośmielił się szargać francuskie świętości”.

${ }^{14}$ D. Beauvois, Mes pierres de lune..., s. 100.

15 Korespondencja prowadzona w latach 1981-1999 składa się z 44 listów, 30 napisanych przez Daniela Beauvois i 14 autorstwa Jerzego Giedroycia. Jej w większości roboczy charakter potwierdza wybór w sumie 8 listów do antologii korespondencji redaktora paryskiej „Kultury” z historykami i świadkami historii; zob. J. Giedroyc, „Mam na Pana nowy zamach...” Wybór korespondencji Jerzego Giedroycia z historykami i świadkami historii 1946-2000, t. 1, wybór i oprac. S.M. Nowinowski, R. Stobiecki, współpr. A. Brzezińska, M. Przybysz-Gralewska, Łódź 2019, s. 107-116. 
Beauvois znał „Kulturę” jako pismo od lat 60., kiedy polecił mu ją jeden $\mathrm{z}$ jego kolegów szkolnych z rodzinnego Béthune, syn polskich emigrantów. Jako czytelnik zetknął się z myślą polityczną Juliusza Mieroszewskiego dotyczącą ułożenia stosunków z Ukrainą, Litwą i Białorusią (tzw. doktryna ULB), której, jak sam przyznawał w 1986 r., czuje się „spadkobiercą duchowym”: „od dwudziestu lat badania moje utwierdzają mnie w przekonaniu, że artykuły pisane przez niego nieprzerwanie do 1976 roku były słuszne i dalekowzroczne"16.

Środowisko „Kultury” do końca lat 70. XX w. znał raczej słabo, po części dlatego, że jak sam zauważał, „,redaktorzy »Kultury« nie przykładali większej wagi do zaznajomienia francuskiego czytelnika $\mathrm{z}$ treścią pisma: »Mimo, że pojawiały się od czasu do czasu specjalne numery pisma $w$ języku niemieckim lub rosyjskim, to jednak francuski nie doczekał jeszcze takiego zaszczytu. Obojętność ta trochę dziwi, gdy wziąć pod uwagę głęboką nieznajomość spraw polskich we Francji i w ogóle na Zachodzie«"17.

O znaczeniu wydawnictw Instytutu Literackiego dla polskiej inteligencji miał okazję przekonać się w Warszawie, gdzie w latach 1969-1972 pełnił funkcję dyrektora Centre de civilisation française - i gdzie uczył się rozumienia polskości.

To Giedroyc - o czym Beauvois nie wiedział - zauważył i w entuzjastycznych słowach oceniał jego monografię Uniwersytetu Wileńskiego w liście do Czesława Miłosza z 29 sierpnia 1977 r. Z jego inicjatywy w grudniowym numerze „Kultury” z 1977 r. ukazała się recenzja Wiktora Sukiennickiego o - jak się później okazało - znamionującym styl badań polonoznawczych francuskiego historyka tytule Weryfikacja legendy ${ }^{18}$. W 1978 r. przypadało czterechsetlecie Uniwersytetu Stefana Batorego, z którą to rocznicą Giedroyc wiązał nadzieje na zorganizowanie znaczącej w międzynarodowym środowisku naukowym jubileuszowej konferencji. Ani on, ani Miłosz, który próbował zainteresować organizacją jubileuszu The American Association for the Advancement of Slavic Studies, nie pomyśleli jednak wówczas o kontakcie z Beauvois, który w tym samym roku przechodził $\mathrm{z}$ pracy badawczej $\mathrm{w}$ Centre nationale de la recherche scientifique na stanowisko kierownika katedry studiów polonoznawczych na uniwersytecie Lille III.

Do Giedroycia napisał po raz pierwszy w kwietniu 1981 r., przesyłając program sesji polonijnej w Lille (Université Lille III, 14-15 maja 1981 r.). Była to spontaniczna reakcja na zamieszczenie $\mathrm{w}$ „Kulturze” informacji o wspomnianym wyżej wydarzeniu. W listopadzie 1984 r. Beauvois gorąco zapraszał Giedroycia do udziału w konferencji poświęconej polskiej prasie emigracyjnej we Francji w latach 1918-1984.

$\mathrm{W}$ tym okresie rolę pośrednika w nawiązaniu bezpośrednich relacji z redakcją „Kultury” odegrał świeżo zatrudniony w CNRS Krzysztof Pomian, którego

16 D. Beauvois, Z perspektywy sympatyka, w: O „Kulturze”. Wspomnienia i opinie, London 1987, s. 107.

17 Tamże, s. 105.

18 W. Sukiennicki, Weryfikacja legendy, „Kultura” 1977, nr 12(363), s. 29-40. 
Beauvois znał jeszcze z czasów warszawskich. We francuskim wydawnictwie Éditions des archives contemporaines (EAC) dobiegały końca prace nad publikacją nowej książki Beauvois. Początkowo planował on wydać polski przekład pracy w Éditions Spotkania ${ }^{19}$, przedstawił maszynopis Giedroyciowi, a ten 26 sierpnia 1985 r. zawiadomił, że przyjmuje książkę do druku ${ }^{20}$.

$\mathrm{W} 1987$ r. Le noble, le serf et le révizor. La noblesse polonaise entre le tsarisme et les masses ukrainiennes (1831-1863) ukazała się w przekładzie Ewy i Krzysztofa Rutkowskich jako 425. tom Biblioteki „Kultury”, pod „lepiej brzmiącym po polsku” - wedle określenia Beauvois ${ }^{21}$ - tytułem Polacy na Ukrainie 1831-1863. Szlachta polska na Wolyniu, Podolu i Kijowszczyźnie.

W pierwszym odruchu zmiana tytułu, na którą nie zdecydowali się ani angielscy, ani dekadę później ukraińscy wydawcy, prowokuje pytania. Entuzjastą jego pierwotnej wersji był także Stefan Kieniewicz ${ }^{22}$. Dlaczego oryginalnie zastosowane określenia, właściwe historii społecznej, zostały zastąpione kategoriami narodowymi? Kto był pomysłodawcą polskiego tytułu? Pewnym zaskoczeniem jest komentarz autora, który sam z powodzeniem dokonywał przekładów literatury polskiej na język francuski:

Zmiana tytułu w wersji polskiej nie pozostawiła niestety śladu w mojej pamięci. [...] Faktem jest, że tematyka polska góruje w książce, nie dziw więc, że chciano to podkreślić w polskim tytule, bez koniecznej woli podkreślenia etnicznej strony. Kto podjął tą decyzję? Może sam J. Giedroyc, może K. Pomian, który wielką rolę grał w[e] wprowadzeniu mej pracy do redakcji, może K. Rutkowski, może ja... Trudno teraz to ustalić ${ }^{23}$.

Zachowana w Archiwum Instytutu Literackiego korespondencja niestety nic w tej kwestii nie wnosi. Treść pracy pozwala jednak zauważyć, że Beauvois idąc tropem rosyjskiej biurokracji z guberni kijowskiej, wołyńskiej i podolskiej, bo tych ziem dotyczy omawiana praca, wyraźnie utożsamia całą polską ludność Kresów ze stanem szlacheckim, ruską zaś (głównie ukraińską) z chłopstwem² ${ }^{24}$.

W momencie gdy Beauvois $z$ inspiracji Wacława Godlewskiego, twórcy ośrodka studiów polonistycznych w Lille, podejmował badania nad historią dawnych wschodnich kresów Rzeczypospolitej, dla przeciętnego Francuza była to rzeczywistość kompletnie nieznana, porównywalna z wyprawą na Księżyc, co

19 Polskie wydawnictwo emigracyjne, od 1985 r. działające w Paryżu, wcześniej w Londynie, red. nacz. Piotr Jegliński.

20 AIL, KR, Beauvois Daniel, List J. Giedroycia do D. Beauvois, Maisons-Laffitte, 26 VIII 1985 r.

${ }^{21}$ D. Beauvois, Mes pierres de lune..., s. 86.

22 S. Kieniewicz, Daniel Beauvois o kresach południowych (w zwiazku z praca D. Beauvois, Le noble, le serf et le révisor. La noblesse polonaise entre le tsarisme et les masses ukrainiennes (1831-1863), Paris-Montreaux 1985), „Przegląd Historyczny” 77, 1986, nr 4, s. 768.

${ }^{23}$ D. Beauvois, e-mail do autorki, 19 VI $2020 \mathrm{r}$.

${ }^{24}$ Był to powód uwag merytorycznych w recenzji książki pióra S. Kieniewicza; zob. tenże, dz. cyt., s. 772. 
w poetycki sposób odnotował w tytule swoich wspomnień (Mes pierres de lune). Było to jednak wrażenie znacznie wyprzedzające powstanie autobiografii, już bowiem w 1988 r. tłumaczył na łamach „Zeszytów Historycznych”:

Kiedy zaglądałem do tych zakurzonych papierów [archiwum Dymitra G. Bibikowa, generalnego gubernatora podolskiego, wołyńskiego i wojennego gubernatora kijowskiego w latach 1837-1852 - A.B.], których nikt przede mną nie miał w ręku, czułem się jakby na księżycu. Kiedy wracałem samolotem z Leningradu do Paryża i nie zabrano mi notatek, miałem wrażenie, jakbym wiózł kamień $\mathrm{z}$ księżyca ${ }^{25}$.

W przedmowie do Polaków na Ukrainie... Krzysztof Pomian wyraził się z entuzjazmem o stanie francuskich badań polonistycznych lat 40.-70. XX w. Jednak ilustrującą tę tezę listę trzech tytułów trudno byłoby powiększyć o znaczące publikacje ${ }^{26}$. Wbrew opinii o „trwałych więziach, jakie łączą znaczną część społeczeństw obu krajów"27, bardziej przekonująco brzmiały słowa Daniela Beauvois, gdy w 1987 r. pisał, że utarło się we Francji przypisywane Alfredowi Jarry’emu (autorowi Króla Ubu) powiedzenie: „rzecz dzieje się w Polsce, to znaczy nigdzie”28.

Niewątpliwym osiągnięciem francuskiego badacza, wskazującym nieobecne dotąd w polskiej historiografii tropy, było dostarczenie argumentacji źródłowej do dwóch kwestii. Po pierwsze miejsca chłopów w społeczeństwie ziem dawnej Rzeczypospolitej w kontekście fenomenu rusyfikacji Kresów Wschodnich. Dostrzegał tu istniejący jeszcze $\mathrm{w}$ czasach przedrozbiorowych brak poczucia polskiej tożsamości narodowej wśród chłopstwa lub wręcz okazywanie obcości kulturowej; wykluczenie społeczne ze strony szlachty przy jednoczesnym głębokim poczuciu przynależności do miejsca pochodzenia („tutejszość”). Po drugie przedstawił wiarygodny obraz symetrii rosyjskiego i polskiego podejścia do ludności ukraińskiej, charakteryzujący się protekcjonalizmem, poczuciem wyższości kulturowej, rozgrywaniem przez obie strony kwestii ukraińskiej niepodległości lub awansu społecznego jako argumentu mającego zjednywać Ukraińców dla jednej lub drugiej ze stron konfliktu polsko-rosyjskiego. I choć w XIX w. państwo polskie nie istniało, w stosunkach narodowościowych na jego niegdysiejszych Kresach Wschodnich uderzyło Beauvois podobieństwo relacji polsko-ukraińskich do francusko-algierskiej rzeczywistości kolonialnej. Dla polskich czytelników było to porównanie szokujące.

25 Anielstwo i imperializm. Wywiad z prof. Danielem Beauvois, „Zeszyty Historyczne” 1988, nr 85 , s. 8.

${ }^{26}$ J. Fabre, Stanislas-Auguste Poniatowski et l'Europe des lumières. Étude de cosmopolitisme, Paris 1952; A. Jobert, La Commission de l'éducation nationale en Pologne (1773-1794). Son œuvre d'instruction civique, Paris 1941, tenże, De Luther à Mohila. La Pologne dans la crise de la Chrétienté 1517-1648, Paris 1974.

27 T. Wyrwa, Stosunki francusko-polskie w okresie „dziwnej wojny” (wrzesień 1939 - czerwiec 1940), „Zeszyty Historyczne” 1989, nr 89, s. 221.

${ }^{28}$ D. Beauvois, $Z$ perspektywy sympatyka... 
Arcyciekawa wreszcie jest postawiona przez Beauvois diagnoza polskiego charakteru narodowego ${ }^{29}$, który cechują według niego „anielstwo” i „imperializm” zarazem:

Każdy naród ma swoje okropne momenty, lecz należy o tym mówić, aby przyszłość była lepsza [...] uważam [że Polacy mają większą niż inne narody skłonność do upiększania własnej historii - A.B.]. Ta tendencja jest u Polaków bardzo silna. Z prostego powodu. Po prostu więcej wycierpieli. Ostatecznie nasze francuskie granice nigdy nie były tak zagrożone jak polskie. Pewnym porównaniem może być naród żydowski. Cierpiał tak okropnie, że ostatnio doszedł do wniosku, że wszystko mu wolno, nawet mordować bezbronnych. Anielskość jest również bardzo silnym znamieniem literatury polskiej. Być może stało się to jakoś podświadomie, lecz w Polakach wyraźnie ugruntowało się przekonanie, że zawsze byli ofiarami, a ich sąsiedzi agresorami. Historia potwierdza takie rozpoznanie, lecz nie zmienia to faktu, że w czasach, gdy [Polska - A.B.] była wielkim mocarstwem, była krajem o aspiracjach imperialistycznych. Nawet w jakiejś recenzji mojej książki wyczytałem, że słowo imperializm nie może być stosowane w odniesieniu do polityki Polski. S.N.: - Ani kolonializm... D.B.: - Właśnie. Zatem przepraszam bardzo, lecz ta kultura była ogromnie zaborcza. Jeśli ukraińskość i litewskość nigdy nie mogły się wybić na niepodległość, to przecież dlatego, że ustawicznie były redukowane przez polskośćc ${ }^{0}$.

Pierwszy nakład książki Beauvois szybko się wyczerpał. Wbrew tezie wywiadu z jej autorem w „Zeszytach Historycznych”31, Jerzy Giedroyć uważał, że emigracja nie przyjęła książki z zainteresowaniem: „Niestety, pierwsze wydanie było bardzo deficytowe, gdyż wzbudziło wielkie zainteresowanie tylko w Polsce, a nie na emigracji, a do Polski musimy wysyłać bezpłatnie"32. Instytut Literacki wznowił 1000 egzemplarzy, lecz tym razem między autorem i wydawcą wyniknęła różnica zdań w sprawie honorarium ${ }^{33}$.

Recepcja Polaków na Ukrainie... w czasopismach Instytutu Literackiego, w odróżnieniu od merytorycznych recenzji prac Beauvois w krajowych czasopismach historycznych ${ }^{34} \mathrm{czy}_{\mathrm{w}}$ prasie, miała raczej charakter kawiarnianych anegdot. W miejsce stereotypu Kresów jako raju utraconego przyjmowano niewątpliwie ciekawą propozycję Beauvois w zasadzie bezkrytycznie, powołując się na „francuski obiektywizm autora", jako gwarancję merytorycznej wartości jego ustaleń.

$\mathrm{Na}$ tym tle mimo wszystko wyróżniał się dość ogólnikowo sformułowany list Józefa Lewandowskiego, który apelował o pogłębienie znajomości realiów polityki

${ }^{29}$ O ile coś takiego w ogóle istnieje; zob. A. Wierzbicki, Spory o polską duszę. Z zagadnień charakterologii narodowej w historiografii polskiej XIX i XX wieku, Warszawa 1993 i wyd. nast.

${ }^{30}$ Anielstwo i imperializm..., s. 7.

31 Tamże, s. 3.

32 AIL, KR, Beauvois Daniel, List J. Giedroycia do D. Beauvois, Maisons-Laffitte, 7 XII 1988 r.

${ }_{33}$ Zob. przyp. 10.

${ }^{34}$ S. Kieniewicz, dz. cyt.; I. Rychlikowa, Deklasacja drobnej szlachty polskiej w Cesarstwie Rosyjskim. Spór o „Pułapkę na szlachtę” Daniela Beauvois, „Przegląd Historyczny” 79, 1988, nr 1, s. 121-147; L. Zasztowt, Koniec przywilejów - degradacja drobnej szlachty polskiej na Litwie historycznej i prawobrzeżnej Ukrainie w latach 1831-1868, „Przegląd Wschodni” 1, 1991, nr 3, s. 615-640; D. Beauvois, Moja przygoda z Kresami, „Ruch Literacki” 1989, nr 4/5, s. 281-291. 
rosyjskiej w pracy francuskiego badacza ${ }^{35} \mathrm{i}$ wskazywał błędy w tłumaczeniu z języka rosyjskiego, pisząc o polskiej ignorancji w sprawach rosyjskich. List jednak - prócz kwestii translatorskich - zupełnie nie dotykał treści książki. W odpowiedzi w numerze listopadowym St. Toper zauważał: „W obliczu tak odkrywczej i pouczającej książki jak Polacy na Ukrainie naprawdę warto by podyskutować o czym innym aniżeli o tym, czy dieło należy raczej pisać delo czy deło" ${ }^{36}$.

Dyskusja jednak nie nastąpiła. W marcu 1989 r. pojawił się wreszcie komentarz trzeci - i ostatni - w dziale „Sprawy i Troski”. Czesław Tynna, autor artykułu, na kanwie wywiadu Beauvois dla „Zeszytów Historycznych” zakwestionował tezę o całkowitej rusyfikacji drobnej szlachty w wyniku polityki ludnościowej gubernatora Bibikowa:

Te 400 tys. osób, o których mówi Autor (str. 9) pozbawionych życia obywatelskiego, bynajmniej nie zniknęło. Przeciwnie, ta zdeklasowana grupa społeczna zachowała w ogromnej większości, także w stanie chłopskim, zarówno swoją świadomość narodową, jak i wyznanie. Ono właśnie było i nadal jest znamienną jej cechą i wartością, pozwalającą jej współczesnym potomkom utożsamiać się z polskim pochodzeniem i rzymskim katolicyzmem ${ }^{37}$.

Brak kwalifikacji warsztatowych do merytorycznej dyskusji, sprowadzanie odbioru książki do sfery emocji w miejsce racjonalnej krytyki pobrzmiewał też w anonimowym sprawozdaniu ze zorganizowanego $\mathrm{z}$ inicjatywy Paryskiego Stowarzyszenia Polsko-Ukraińskiego i Towarzystwa Historyczno-Literackiego spotkania $\mathrm{z}$ autorem w Bibliotece Polskiej 11 grudnia 1993 r.: „Daniel Beauvois udowodnił, że drobną szlachtę czynszową wygnali z domów po Powstaniu Styczniowym właściciele majątków ziemskich. Czyli, że Polacy wygnali Polaków”38.

Mimo rozczarowującej recepcji książki wśród emigracji, Polacy na Ukrainie... nie byli jedyną pracą Beauvois, na której przekładzie zależało Giedroyciowi. Prawdopodobnie nawet chętniej wydałby monografię Uniwersytetu Wileńskiego ${ }^{39}$, jednak prawa do polskiego przekładu wcześniej (w 1979) nabyło krakowskie Wydawnictwo Literackie. Gdy umowa wygasła w lutym 1987 r., Beauvois przesłał maszynopis do Maisons-Laffitte. 5 grudnia 1987 r. redaktor „Kultury” poinformował jednak autora o rezygnacji z praw do druku: „Piszę z największą przykrością, że nie jestem w stanie wydać Pana książki o Uniwersytecie Wileńskim, jakkolwiek uważam tę książkę za niezmiernie ważną. Przeszkodą są koszty"40.

35 J. Lewandowski, Listy do redakcji, „Kultura” 1988, nr 9(492), s. 169-171.

36 S. Toper, Listy do redakcji, „Kultura” 1988, nr 11(494), s. 160. Józef Lewandowski odniósł się do stawianych mu zarzutów, w dalszym ciągu jednak wyłącznie w kontekście jakości przekładu i ogólnego stanu wiedzy o Rosji w PRL; tenże, Listy do redakcji, „Kultura” 1989, nr 3(498), s. 169-170.

${ }^{37}$ C. Tynna, Polacy na Ukrainie, „Kultura” 1989, nr 3(498), s. 106.

38 Spotkanie polsko-ukraińskie w Paryżu, „Kultura” 1994, nr 1(556), s. 152-153.

39 D. Beauvois, Szkolnictwo polskie na ziemiach litewsko-ruskich 1803-1832, t. 1: Uniwersytet Wileński, t. 2: Szkoły podstawowe i średnie, tłum. I. Kania, Rzym-Lublin 1991.

${ }^{40}$ AIL, KR, Beauvois Daniel, List J. Giedroycia do D. Beauvois, Maisons-Laffitte, 5 XII 1987 r. 
Jak żartem skomentował w swojej autobiografii autor, ostatecznie polski przekład umożliwił Jan Paweł II, który podczas kolokwium polskiego w Castel Gandolfo w 1990 r. publicznie zobowiązał Jerzego Kłoczowskiego do wydania studium o Uniwersytecie Wileńskim na KUL, ponieważ czytał książkę i uważał ją za wartościową. Toteż 3 października 1991 r. Giedroyc mógł napisać do Beauvois: „A więc nareszcie wyszła Pana książka o Uniwersytecie Wileńskim. Kiedy można się spodziewać drugiego tomu? Organizuję teraz zakup i wysyłkę tej książki do ważniejszych ośrodków naukowych litewskich i ukraińskich"41.

Dwa lata później, 29 listopada 1993 r. deklarował z kolei: „proszę o wiadomość, czy ostatecznie Wydawnictwo Uniwersytetu Wrocławskiego podjęło się wydania Pana książki »La bataille de la terre«. Jeśli główną trudnością jest brak pieniędzy, to będę mógł próbować uzyskać dla nich dotację"42.

Ciekawym epizodem współpracy wydawniczej Beauvois z „Kulturą” była propozycja polskiego przekładu pracy jego syna, Yvesa, dotyczącej relacji polsko-francuskich podczas „dziwnej wojny”43, na który Giedroyc się nie zdecydował. Francuskie wydanie książki polecił zrecenzować Tadeuszowi Wyrwie, który pisał:

Na Zachodzie - gdy mowa jest o Polsce niepodległej z dwudziestolecia - modne jest pisanie o „dyktaturze”, „faszyzmie”, polityce „germanofilskiej” Piłsudskiego i Becka; tej modzie uległ niestety i Yves Beauvois. Dzisiaj pojęcia te - po dyktaturach Hitlera i Mussoliniego oraz zbrodniach ustrojów faszystowskich - nie powinny być w żadnym wypadku używane w stosunku do rządów, które - jak w Polsce - były autorytatywne, ale nie dyktatorskie. [...] Książka Yves Beauvois przyczyni się może do zdania sobie wreszcie sprawy z nieodzownej potrzeby przemyślenia, bez kompleksów i uprzedzeń, historii stosunków polsko-francuskich, nad którymi stale ciążą dawne stereotypy, przekazywane z jednego pokolenia na drugie, z ogromną szkodą dla trwałych więzi, jakie łączą znaczną część społeczeństw obu krajów, czego nie powinno się mieszać ze stosunkami w dziedzinie politycznej i z nieprzerwanie odtwarzanymi mitami, które prawdzie historycznej służyć nie mogą ${ }^{44}$.

Przy całej otwartości Jerzego Giedroycia na demitologizację polskich stereotypów historycznych w odniesieniu do historii, której sam był świadkiem, (tym razem?) instynkt go zawiódł. Może w imię ochrony dobrej opinii o politycznej

${ }^{41}$ Tamże, List J. Giedroycia do D. Beauvois, Maisons-Laffitte, 3 X 1991 r.

42 Tamże, List J. Giedroycia do D. Beauvois, Maisons-Laffitte, 29 XI 1993 r.

${ }^{43}$ Y. Beauvois, Stosunki polsko-francuskie w czasie „dziwnej wojny”, tłum. I. Kania, Kraków 1991, s. 172.

${ }^{44}$ T. Wyrwa, dz. cyt., s. 218, 221. W 1991 r. polski przekład książki Y. Beauvois ukazał się nakładem krakowskiej Oficyny Literackiej: Y. Beauvois, Stosunki polsko-francuskie... Praca stanowi bardzo interesujący przykład interpretacji historii Polski XX w. w kategoriach francuskiej filozofii politycznej. Nie są one oczywiste dla polskiego odbiorcy, a zdanie sobie sprawy z różnic jest konieczne, by rozumieć miejsce Polski w polityce europejskiej; zob. szerzej: J.E. Zamojski, Polskie sprawy w „dziwnej wojnie” Francuzów, „Dzieje Najnowsze” 22, 1990, nr 1-2, s. 169-178. Szczególnej aktualności praca nabiera obecnie, w kontekście rosyjskiej polityki historycznej dotyczącej genezy II wojny światowej. 
intuicji Piłsudskiego, w którą wierzył. I co do której wiedział, że była stałym celem ataków historiografii marksistowsko-leninowskiej w PRL. Yves Beauvois opisywał historię Polski tak, jak rozumiano ją w ówczesnej Francji, gdzie akademicki dyskurs o krajach słowiańskich tradycyjnie wyznaczali badacze dziejów Rosji. I w której Polonia - poza „Kulturą” - nie protestowała tłumnie przeciwko zmianie nazwy Centre d'histoire des Slaves na Centre d'histoire des Slaves, des Russes et de l'Union Sovietique na paryskiej Sorbonie ${ }^{45}$.

Jak pisał Fernando Sánchez-Marcos, wielkim powołaniem historyka jest rola tłumacza - pośrednika między kulturami ${ }^{46}$. Ważnym wątkiem, choć pobrzmiewającym tylko w tle historycznej publicystyki Daniela Beauvois, jest jeszcze jedna grupa stereotypów - polsko-francuska. Jego próby zrozumienia polskiej mentalności, zaskoczenie reakcją polskich odbiorców na uzasadnioną materiałem źródłowym krytykę, stopniowo doprowadziły go do przekonania o istnieniu głębokich różnic w rozumieniu przez Polaków i Francuzów zasadniczych wartości kulturowych i obywatelskich.

Przykładem tego może być kategoria wolności, jakże często uznawana przez obie strony za wartość najwyższą. Jednak wolność francuska i polska różnią się fundamentalnie. Wskutek doświadczenia rozbiorów Polacy rozumieli ją głównie w sensie narodowowyzwoleńczym, doświadczenie PRL budziło tęsknotę za wolnością od aparatu państwowego, uznawanego za obcy, postawy antyobywatelskie (przeciw definicji obywatela postulowanej przez władzę ludową) wartościowano moralnie dodatnio. W rozumieniu francuskim natomiast wolność ma właśnie charakter obywatelski, oparty na mocnym fundamencie republikańskim. Podobnych przykładów można zapewne wskazać więcej - i z pewnością zasługują one na odrębną uwagę.

W cytowanej już recenzji książki Beauvois Stefan Kieniewicz zauważył, że: „Cudzoziemiec, który się bierze do pisania o polskim narodzie, zawsze naraża się, że czegoś nie rozumie, czegoś nie dopatrzy, czyjąś miłość własną zadraśnie" ${ }^{\prime 7}$. Paradoks polega chyba na tym, że Beauvois zrozumiał polską duszę dobrze, może nawet lepiej, niż wskazywałyby na to źródła historyczne, których przecież wyczerpać ostatecznie nie sposób. Jako profesjonalny tłumacz literatury polskiej intuicyjnie wykorzystał to zawodowe doświadczenie w swojej pracy historycznej, wpisując się w postulowaną przez Sáncheza-Marcosa rolę badacza przeszłości - pośrednika kultur. W wymiarze naukowym dało mu to poczucie spełnienia. $\mathrm{Na}$ poziomie emocjonalnym fascynacja kulturą polską przyniosła mu jednak rozczarowanie. Prawdopodobnie dlatego odmówił udziału w ostatnim numerze „Zeszytów Historycznych”:

45 J. Giedroyc, Notatki Redaktora, „Kultura” 1997, nr 11(602), s. 144.

${ }^{46}$ F. Sánchez-Marcos, Historyk jako tłumacz, „ER(R)GO. Teoria - Literatura - Kultura” 2, 2001, nr 3, s. 61.

${ }^{47}$ S. Kieniewicz, dz. cyt., s. 775. 
Dziękuję więc bardzo serdecznie i przepraszam. Myślę, że na swój sposób honoruję dalej światłą pamięć wielkiego Redaktora. W 2010 ma się ukazać we Wrocławiu wznowienie mojej Historii Uniwersytetu Wileńskiego (1709-1832), a w Moskwie szykuje się zbiór moich trzech książek o Polakach na Ukrainie po rosyjsku [...]. Szkoda, że już nie będzie można tego zrecenzować w Z.H... ${ }^{48}$.

\section{Bibliografia}

\section{Źródła}

Archiwum Instytutu Literackiego w Maisons-Laffitte, Korespondencja redakcyjna, Beauvois Daniel D. Beauvois, e-mail do autorki, 19 VI 2020 r.

\section{Opracowania}

Anielstwo i imperializm. Wywiad z prof. Danielem Beauvois, „Zeszyty Historyczne” 1988, nr 85, s. $3-12$

D. Beauvois, Autobiografia i teksty wybrane, Warszawa 2017

D. Beauvois, Mes pierres de lune. Essai d’autobiographie professionnelle, „Organon” 2014, nr 46, s. 11-169

D. Beauvois, Moja przygoda z Kresami, „Ruch Literacki” 1989, nr 4/5, s. 281-291

D. Beauvois, Le noble, le serf et le révizor. La noblesse polonaise entre le tsarisme et les masses ukrainiennes, 1831-1863, Paris 1985

D. Beauvois, Szkolnictwo polskie na ziemiach litewsko-ruskich 1803-1832, t. 1: Uniwersytet Wileński, t. 2: Szkoly podstawowe i średnie, tłum. I. Kania, Rzym-Lublin 1991

D. Beauvois, Z perspektywy sympatyka, w: O „Kulturze”. Wspomnienia i opinie, London 1987, s. 107$-110$

Y. Beauvois, Les relations franco-polonaises pendant la „drôle de guerre”, wstęp R. Girault, Paris 1989

Y. Beauvois, Stosunki polsko-francuskie w czasie „dziwnej wojny”, tłum. I. Kania, Kraków 1991

A. Brzezińska, Autoportret $z$ Klio. Ego-histoire kontra historia historyka Arona Guriewicza jako koncepcja źródła w biografii historyka, „Sensus Historiae” 17, 2014, nr 4, s. 213-223

R. Darnton, The Great Cat Massacre and Other Episodes in French Cultural History, New York 1984; wyd. pol.: Wielka masakra kotów i inne epizody francuskiej historii kulturowej, tłum. D. Guzowska, Warszawa 2012

N. Davies, Sam o sobie, tłum. B. Pietrzyk, Kraków 2019

Essais d'ego-histoire, red. P. Nora, Paris 1987

J. Fabre, Stanislas-Auguste Poniatowski et l'Europe des lumières. Étude de cosmopolitisme, Paris 1952 M. Filipowicz, Konferencja w Lille, „Kultura” 1993, nr 11(554), s. 57-59

J. Giedroyc, „Mam na Pana nowy zamach...” Wybór korespondencji Jerzego Giedroycia z historykami i świadkami historii 1946-2000, t. 1, wybór i oprac. S.M. Nowinowski, R. Stobiecki, współpr. A. Brzezińska, M. Przybysz-Gralewska, Łódź 2019

J. Giedroyc, Notatki Redaktora, „Kultura” 1997, nr 11(602), s. 144

A. Jobert, La Commission de l'éducation nationale en Pologne (1773-1794). Son cuvre d'instruction civique, Paris 1941

A. Jobert, De Luther à Mohila. La Pologne dans la crise de la Chrétienté 1517-1648, Paris 1974

${ }^{48}$ AIL, KR, Beauvois Daniel, List D. Beauvois do W. Sikory, Paryż, 21 I 2010 r. 
S. Kieniewicz, Daniel Beauvois o kresach południowych (w związku z praca D. Beauvois, Le noble, le serf et le révisor. La noblesse polonaise entre le tsarisme et les masses ukrainiennes (1831-1863), Paris-Montreaux 1985), „Przegląd Historyczny” 77, 1986, nr 4, s. 767-775

L. Kuk, Polska z bliska i z oddali. Przypadek Daniela Beauvois w świetle jego wspomnień, „Kwartalnik Historyczny" 124, 2017, nr 4, s. 805-820

J. Lewandowski, Listy do redakcji, „Kultura” 1988, nr 9(492), s. 169-171; 1989, nr 3(498), s. 169-170

I.H. Pugacewicz, rec.: D. Beauvois: Mes pierres de lune. Essai d'autobiographie professionnelle, „Organon”, nr spec. 46, Warszawa 2014, ss. 193, „Kwartalnik Historii Nauki i Techniki” 61, 2016, nr 1, s. 189

I. Rychlikowa, Deklasacja drobnej szlachty polskiej w Cesarstwie Rosyjskim. Spór o „Pułapkę na szlachtę” Daniela Beauvois, „Przegląd Historyczny” 79, 1988, nr 1, s. 121-147

F. Sánchez-Marcos, Historyk jako tłumacz, „ER(R)GO. Teoria - Literatura - Kultura” 2, 2001, nr 3 , s. $61-73$

Spotkanie polsko-ukraińskie w Paryżu, „Kultura” 1994, nr 1(556), s. 152-153

W. Sukiennicki, Weryfikacja legendy, „Kultura” 1977, nr 12(363), s. 29-40

S. Toper, Listy do redakcji, „Kultura” 1988, nr 11(494), s. 160

C. Tynna, Polacy na Ukrainie, „Kultura” 1989, nr 3(498), s. 106

A. Wierzbicki, Spory o polska duszę. Z zagadnień charakterologii narodowej w historiografii polskiej XIX i XX wieku, Warszawa 1993 i wyd. nast.

T. Wyrwa, Stosunki francusko-polskie w okresie „dziwnej wojny” (wrzesień 1939-czerwiec 1940), „Zeszyty Historyczne” 1989, nr 89, s. 221

J.E. Zamojski, Polskie sprawy w „dziwnej wojnie” Francuzów, „Dzieje Najnowsze” 22, 1990, nr 1-2, s. $169-178$

L. Zasztowt, Koniec przywilejów - degradacja drobnej szlachty polskiej na Litwie historycznej i prawobrzeżnej Ukrainie w latach 1831-1868, „Przegląd Wschodni” 1, 1991, nr 3, s. 615-640

\section{Le noble, le serf et le révizor: Daniel Beauvois in the Library of „Culture”}

This article deals with Daniel Beavois - a distinguished student of the Polish Russian Ukrainian relations in the post-partitioned era - and his contacts with the editors of the Paris 'Kultura'. The author's concern is also with the question of how Beavois' work on the Polish nobility in Ukraine in the years 1831-1863 was received among Polish post-war exiles, and with Beavois' postcolonial diagnosis that emerged on the margins of his research and concerned the tensions to which Polish national identity was subject in Poland's old eastern borderland (the so-called Kresy).

The article is based on Daniel Beavois' autobiography, the volumes of Kultura containing references to the Poles in Ukraine and Beavois' correspondence with Giedroyc (the one still surviving in Maisons-Laffitte). Daniel Beavois' first encounter with the Paris Kultura took place in the 1960s. In Giedroyc's correspondence the French scholar's name first appeared in a letter which Giedroyc wrote on 29 August 1977 to Czesław Miłosz. The letter contains an enthusiastic review of Beavois' book on the Vilnius University. Beavois first turned to Giedroyc in 1981, but it was not until four years later that he, thanks to Krzysztof Pomian, established closer contact with Kultura's editorin-chief. In 1987, the Polish translation of Beavois' pioneering work Le noble, le serf et le révizor. La noblesse polonaise entre le tsarisme et les masses ukrainiennes (1831-1863) was published in the Library of the Paris 'Kultura'. As opposed to the work's reviews that appeared in Communist Poland and actually tried to address its strengths and weaknesses, the reception of it in the journals published by the Institut Litteraire is rather disappointing. While rejecting the stereotypical view of 
Poland's old eastern borderland as the Paradise Lost, the journals' contributors uncritically accepted Beavois' theses on the grounds that 'his French objectivism' guaranteed the scholarly soundness of his findings. Giedroyc attempted to publish Beavois' book on the Vilnius University, but his efforts were frustrated by financial problems.

A fascinating theme that runs throughout Beavois' works, which requires further analysis, concerns the postcolonial diagnosis of the tensions to which Polish national identity was subject in Poland's old eastern borderland. The metaphorical extremes of this tension are constituted by the idea of "angelicness" (Poland as a victim of aggression) and 'imperialism' (Polish culture's 'rapacity' in Poland's old eastern borderland). Upholding the myth of Polish 'angelicness' is increasingly followed by a rejection of the French scholar's findings and has finally led him to wish for the Poles to start treating history as a 'reason to think and not to feel proud'.

Anna Brzezińska - historyczka historiografii, adiunkt w Katedrze Historii Historiografii i Nauk Pomocniczych Historii Uniwersytetu Łódzkiego, członek redakcji „Historia@Teoria”, „Rocznik Antropologii Historii” (2011-2016); uczestniczka grantu „Jerzy Giedroyc, historycy i świadkowie historii" (2014-2019, kierownik: prof. dr hab. R. Stobiecki). Zainteresowania badawcze: historiografia polska i powszechna XX w., historia intelektualna, mediewistyka w interpretacjach francuskiej szkoły „Annales”, antropologia historyczna. Autorka m.in. Spór o średniowiecze. Z rozważań nad tożsamością kulturowa Europy: Jacques Le Goff, Jerzy Kłoczowski, Aron Guriewicz, Łódź 2018. E-mail: anna.brzezinska@uni.lodz.pl 